\title{
Karakteristik Distribusi Temperatur Build Part pada Proses Pressureless Indirect Sintering
}

\author{
Susilo Adi Widyanto dan Syaiful \\ Jurusan Teknik Mesin, Fakultas Teknik, Universitas Diponegoro Semarang \\ Email: susilo70@yahoo.com
}

\begin{abstract}
ABSTRAK
Fenomena curling pada produk rapid prototyping (RP) merupakan persoalan aktual yang belum teratasi dengan baik. Demikian halnya pada produk hasil proses multi material deposition indirect sintering (MMD-Is). Salah satu penyebabnya adalah distribusi temperatur build part yang tidak seragam. Berbeda dengan proses sintering pada mesin-mesin RP pada umumnya, sintering pada proses MMD-Is dikerjakan dalam lingkungan supporting powder dengan sumber panas berasal dari luar dinding build part. Penelitian ini bertujuan untuk menentukan pengaruh bahan supporting powder, ukuran partikel dan konfigurasi sistem pemanas pada distribusi temperatur build part. Distribusi temperatur diukur dengan membenamkan beberapa termokopel di dalam supporting powder yang menyatakan variasi posisi radial maupun vertikal. Hasil penelitian menunjukkan bahwa ketidakseragaman temperatur build part antara lain disebabkan oleh fenomena pemanasan sekunder oleh bahan piston.
\end{abstract}

Kata kunci: Distribusi temperatur, supporting powder, build part.

\begin{abstract}
Curling phenomenon on rapid prototyping (RP) product is an actual problem which has not been solved clearly, also on MMD-Is product. Previous experiment showed, it was caused dominantly by un-uniformity of temperature distribution in build part system when sintering was executed. Differ to the sintering process in the common commercial RP process, sintering process in MMD-Is is conducted in supporting powder media. The research is aimed to observe the effect of supporting powder materials, particle size and configuration of heater system on temperature distribution of the build part. Temperature distribution was measured by immersing thermocouples into supporting powder in vertical and horizontal formation. The experimental results show that the un-uniformity of the build part temperature is caused by secondary heating phenomenon by piston material at base position.
\end{abstract}

Keywords: Temperature distribution, supporting powder, build part.

\section{PENDAHULUAN}

Pengembangan mesin-mesin RP terus dilakukan untuk meningkatkan kualitas produk, mereduksi ongkos operasi maupun untuk tujuan pengembangan produk-produk khusus. Proses MMD-Is merupakan salah satu pengembangan proses RP untuk pembuatan produk-produk multi material. Berbeda dengan mesin-mesin RP komersial pada umumnya, pendeposisian serbuk (meliputi serbuk produk dan supporting powder) pada proses MMD-Is dipisahkan dari proses sinteringnya. Hal ini menghasilkan beberapa keuntungan antara lain: 1). Konstruksi mesin MMD-Is dapat hanya berupa mesin pendeposisi serbuk produk dan supporting powder (MMD), 2). Proses sintering dapat dilakukan secara terpisah menggunakan mesin furnace pada umumnya. Kondisi ini memberikan keleluasaan pada proses pemilihan bahan produk, 3). Produk yang dihasilkan dapat berupa produk multi material yang pada pengembangan lebih lanjut dapat digunakan sebagai dasar pembuatan produk-produk smart material.

Setelah siklus deposisi selesai dilakukan hingga membentuk geometri obyek tiga dimensi dalam tatanan serbuk, proses sintering dilaksanakan. Terdapat dua alternatif pelaksanaan proses sintering, yaitu: 1). Build part dilepaskan dari 
konstruksi mesin deposisi dan sintering dilakukan di dalam furnace, 2). Sintering terintegrasi di dalam mesin deposisi sehingga build part tidak perlu dilepas dari mesin deposisi. Energi sintering dihasilkan oleh sistem pemanas elektris yang dipasangkan melingkupi dinding build part. Namun dengan teknik ini, temperatur sintering relatif rendah dan pengaruh distribusi temperatur pada akurasi dimensi produk perlu diteliti lebih lanjut.

Dari hasil pembuatan contoh-contoh produk diperoleh bahwa akurasi dimensi produk dipengaruhi oleh parameter proses sintering, parameter proses deposisi, ukuran serbuk produk dan ukuran supporting powder [1]. Dengan proses sintering yang dilakukan dalam build part dimana sumber panas berasal dari sistem pemanas elektris diperoleh bahwa untuk produk-produk berketebalan tinggi (di atas $8 \mathrm{~mm}$ dan berbentuk padatan), bagian tengah produk cenderung membentuk cekungan (biasa disebut fenomena curling). Dari hasil pengukuran didapatkan bahwa perbedaan temperatur aktual terjadi antara temperatur bahan produk dan temperatur supporting powder yaitu sekitar $15^{\circ} \mathrm{C}$ (pengesetan temperatur sintering adalah $145^{\circ} \mathrm{C}$ selama 2,5 jam).

Berdasarkan analisis awal, distribusi temperatur build part dipengaruhi oleh bahan dan karakteristik supporting powder serta konfigurasi sistem pemanas elektris yang digunakan. Untuk itu, penelitian ini ditujukan untuk menentukan pengaruh bahan dan ukuran partikel supporting powder serta instalasi sistem pemanas pada distribusi temperatur build part dalam arah vertikal maupun horisontal.

Secara umum fenomena perpindahan panas yang terkait dalam media serbuk meliputi konduksi, radiasi dan konveksi dimana perpindahan panas secara konduksi biasanya paling dominan [2]. Pengaruh konduksi dipengaruhi oleh konduktivitas bahan padat, karakteristik kontak antar partikel (kontak konduktansi) dan struktur pengepakan partikel. Kontribusi radiasi bergantung pada temperatur dan secara signifikan terjadi pada temperatur tinggi (>1000 K). Konveksi dan konduksi yang terjadi melalui melalui pori-pori dapat diabaikan bila proses pemanasan dilakukan pada suhu rendah sampai sedang dimana pada kondisi tersebut konduktivitas termal fluida pengisi ruang kosong bernilai minimal.

Mekanisme perpindahan panas dalam serbuk statis (tidak terdapat aliran fluida) dapat digambarkan sebagai berikut $[3,4]$ :

a. Konduksi termal terjadi melalui fluida stagnan (not flowing).

b. konduksi termal melalui padatan.

c. konduksi termal melalui bidang kontak antara dua partikel.

d. Perpindahan panas radiasi antar permukaan partikel. e. Perpindahan panas radiasi antara ruang yang kosong.

Namun, bila terdapat aliran fluida maka mekanisme berikut perlu dipertimbangkan.

a. Konduksi termal melalui lapisan tipis fluida dekat permukaan bidang kontak dari dua partikel.

b. Perpindahan panas melalui konveksi padat-cairpadat.

Konduktansi kontak adalah kemampuan dua material yang bersentuhan untuk menghantarkan panas pada lapisan antarmukanya. Pemahaman dasar dalam konduktansi kontak adalah bahwa dalam perpindahan panas antar dua partikel halus pada kontak elastis, jari-jari kelengkungan partikel (dianggap berbentuk bola) diasumsikan jauh lebih besar daripada daerah kontak. Mekanisme utama perpindahan panas berupa konduksi melalui kontak permukaan partikel yang saling berhimpitan [5, 6]. Semua solusi tersebut bertujuan untuk memprediksi harga konduktansi kontak, yang nilainya adalah:

$H c=h A$

di mana: $h$ adalah koefisien perpindahan panas, $A$ adalah bidang kontak. Kontak elastis harganya bervariasi tergantung gaya normal yang bekerja yang besarnya adalah:

$H_{c} x F_{n}^{1 / 2}$

Konduktansi kontak termal untuk bidang kontak partikel berbentuk bola (sphere) linier yang elastis dapat dinyatakan oleh:

$\frac{H_{c}}{k_{S}}=2\left[\frac{3 F_{n} r^{\prime \prime}}{4 E^{\prime \prime}}\right]$

dengan;

$H_{c}=$ konduktansi $\operatorname{kontak}\left(\mathrm{W} / \mathrm{m}^{2} \mathrm{~K}\right)$

$k_{s}=$ konduktivitas material padat $(\mathrm{W} / \mathrm{m} \mathrm{K})$

$F_{n}=$ gaya normal $(\mathrm{N})$

$E=$ Modulus Young efektif untuk kedua partikel (GPa)

$r=$ jari-jari partikel rata-rata (mikron)

Jari-jari partikel rata-rata $(r)$ dapat dihitung dengan persamaan.

$$
\begin{aligned}
& \frac{1}{E^{\prime \prime}}=\frac{1-v 1^{2}}{E_{1}}+\frac{1-v 2^{2}}{E_{2}} \\
& \frac{1}{r^{\prime \prime}}=\frac{1}{r_{i}}+\frac{1}{r_{j}}
\end{aligned}
$$

di mana: $E_{i}=$ Modulus Young dan $v_{i}$ adalah rasio Poisson.

Berbeda dengan model perpindahan panas konduksi dalam material padat, konduksi pada serbuk bersifat lokal tergantung pada suhu, kondisi 
daerah batas antar partikel dan porositas lokal. Yagui dan Kunni telah merumuskan suatu model matematik untuk menentukan harga konduktivitas efektif suatu serbuk dengan mempertimbangkan efek konduksi, konveksi dan radiasi yang dinyatakan dalam bentuk Persamaan 6 [7]:

$k_{e}=\frac{\mu k_{s}}{1+\phi \frac{k_{s}}{k_{g}}}$

Dengan fraksi padat (solid fraction) dihitung dengan Persamaan 7:

$\mu=\frac{\rho_{p}}{\rho_{s}}$

Dengan;

$k_{e}=$ konduktivitas efektif (W/m K)

$k_{s}=$ konduktivitas solid material $(\mathrm{W} / \mathrm{m} \mathrm{K})$

$k_{g}=$ konduktivitas udara $(\mathrm{W} / \mathrm{m} \mathrm{K})$

$\mu=$ solid fraction

$\rho_{p}=$ densitas serbuk $\left(\mathrm{kg} / \mathrm{m}^{3}\right)$

$\rho_{s}=$ densitas material padatan $\left(\mathrm{kg} / \mathrm{m}^{3}\right)$

$\Phi=$ koefisien empiris $\left(0.02 \times 10^{2(0.7-\mu)}\right)$

\section{METODE PENELITIAN}

Penelitian ini dilaksanakan dengan metode sebagai berikut:

\section{Material}

Bahan supporting powder yang diteliti berupa serbuk besi cor, serbuk kuningan, serbuk aluminium dan serbuk silika. Ukuran partikel serbuk silika divariasikan meliputi ukuran 100, 150 dan $297 \mu \mathrm{m}$. Pemisahan ukuran dilakukan dengan proses sieving.

Tabel 1. Karakteristik Termal dan Fisik Bahan Supporting Powder

\begin{tabular}{lcc}
\hline Bahan & $\begin{array}{c}\text { Konduktivitas termal } \\
\boldsymbol{k}-(\boldsymbol{W} \mathbf{m K}) \mathbf{- 2 5 ^ { \circ } \boldsymbol { C }}\end{array}$ & $\begin{array}{c}\text { Massa jenis } \\
(\mathbf{k g} / \mathbf{l})\end{array}$ \\
\hline Besi cor & 55 & 7,9 \\
Silika & 1.7 & 2,2 \\
Kuningan & 109 & 8,4 \\
Aluminium & 250 & 2,7 \\
\hline
\end{tabular}

Konstruksi Build Part dan Pengukuran Distribusi Temperatur

Dalam mesin MMD-Is build part berfungsi untuk lokasi pendeposisian serbuk produk dan supporting powder serta pelaksanaan proses sintering. Untuk fungsi tersebut, piston build part harus dapat bergerak dalam arah vertikal yang menentukan ketebalan lapisan obyek tiga dimensi yang akan dibuat. Dalam penelitian ini suatu sistem pemanas dipasangkan menyelubungi dinding build part dengan konstruksi ditunjukkan dalam Gambar 1.

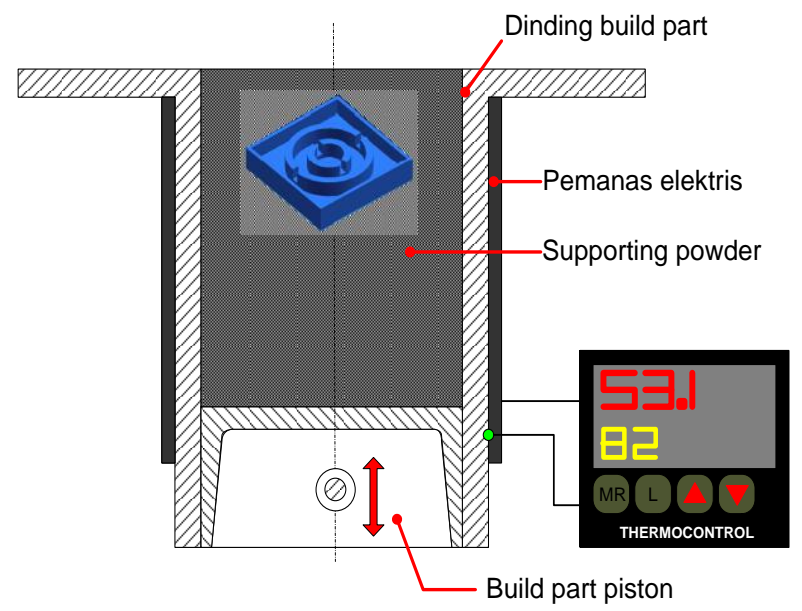

Gambar 1. Konstruksi Build Part

Distribusi temperatur diukur dengan alat ukur temperatur multi kanal, dengan membenamkan sensor termokopel sebagai fungsi posisi radial dan kedalaman seperti ditunjukkan Gambar 2. Pengukuran temperatur dilakukan sejak sistem kendali temperatur dihidupkan (selama 90 menit) hingga supporting powder mencapai temperatur normal setelah sistem kendali dimatikan. Batas temperatur ditentukan pada $150^{\circ} \mathrm{C}$. Pengukuran distribusi temperatur ini dilakukan pada setiap perubahan parameter penelitian (bahan supporting powder dan ukuran partikelnya).

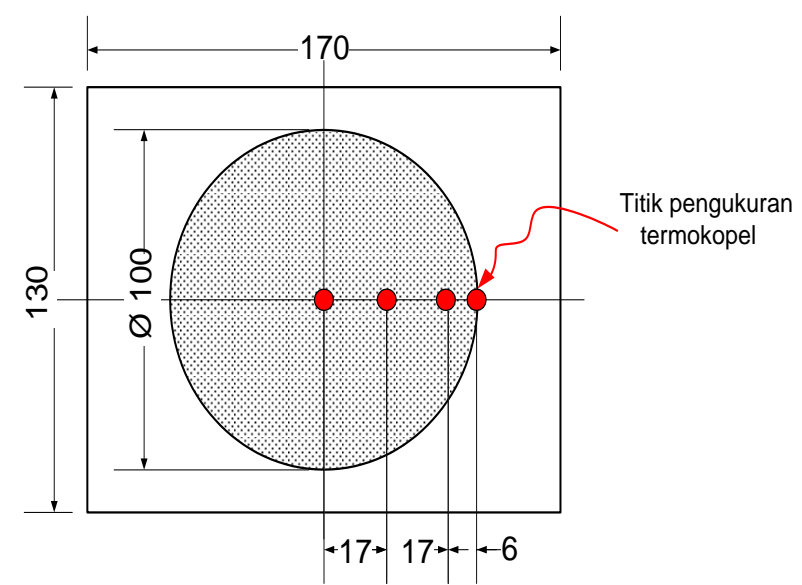

(a) Fungsi posisi posisi radial

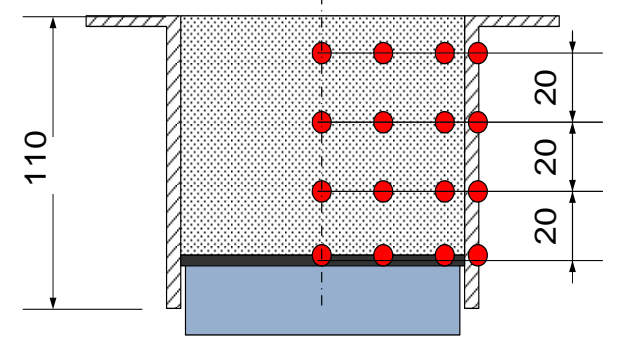

(b) Fungsi posisi vertikal

Gambar 2. Posisi Pengukuran Temperatur 


\section{HASIL DAN PEMBAHASAN}

\section{Distribusi Temperatur pada Arah Radial}

Dari hasil pengujian temperatur pada variasi arah radial diperoleh bahwa distribusi temperatur build part tidak merata hingga proses pemanasan selama 90 menit. Kondisi temperatur tiap-tiap titik ukur seperti dinyatakan dalam Gambar 3. Dari tiga kurva pemanasan tersebut (selama 30, 60 dan 90 menit) didapatkan bahwa panas merambat dari dinding build part (merupakan lokasi penempelan sistem pemanas) menuju ke dalam. Semakin ke tengah sistem build part, laju pemanasan semakin turun.

Penggunaan dua sistem pemanas memperbaiki distribusi temperatur build part baik pada arah radial maupun arah vertikal. Untuk konsumsi energi listrik yang sama (800 watt), penggunaan sistem pemanas ganda menghasilkan aliran panas yang lebih besar dibandingkan penggunaan sistem pemanas tunggal. Kondisi ini menunjukkan bahwa temperatur tidak terdistribusi merata pada permukaan sistem pemanas. Perbandingan distribusi temperatur dalam build part yang dihasilkan oleh pemanas tunggal dan ganda seperti ditunjukkan dalam Gambar 4.

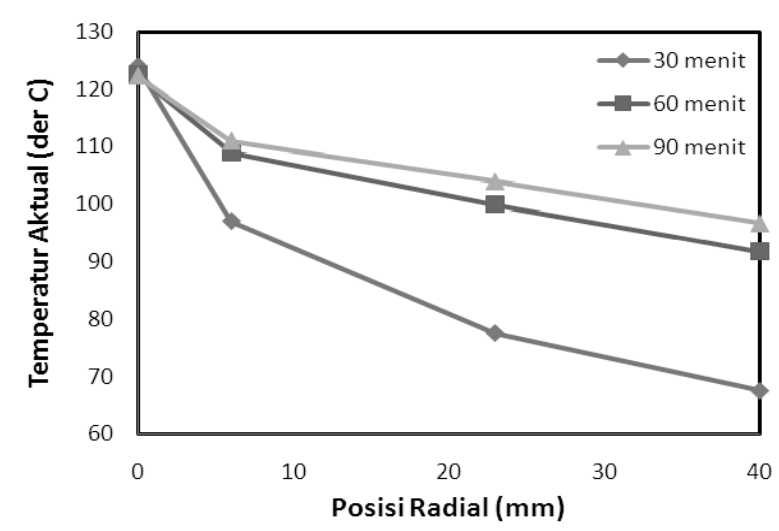

Gambar 3. Distribusi Temperatur pada Build Part ke Arah Radial

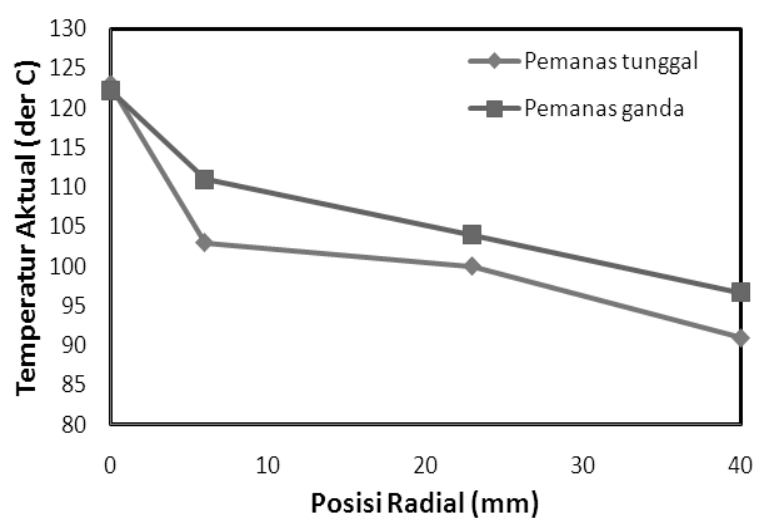

Gambar 4. Distribusi Temperatur Build Part ke Arah Radial dengan Pemanas Tunggal dan Ganda

\section{Variasi Posisi Vertikal}

Dari hasil pengukuran distribusi temperatur arah vertikal diperoleh bahwa temperatur menurun terhadap posisi yang menjauhi permukaan piston baik untuk sistem pemanas tunggal maupun pemanas ganda (Gambar 5 dan 6). Kondisi tersebut membuktikan bahwa permukaan piston juga berfungsi sebagai sumber panas sekunder bagi supporting powder dimana perambatan panas pada bahan piston lebih baik dibandingkan perambatan panas bahan supporting powder (silika).

Penggunaan sistem pemanas ganda menghasilkan distribusi termal yang jauh lebih baik dibandingkan penggunaan sistem pemanas tunggal. Kondisi ini menunjukkan bahwa distribusi temperatur di permukaan sistem pemanasnya sendiri tidak seragam. Hal yang sama dijumpai pada proses laser sintering dimana distribusi panas pada spot laser terdistribusi secara Gaussian.

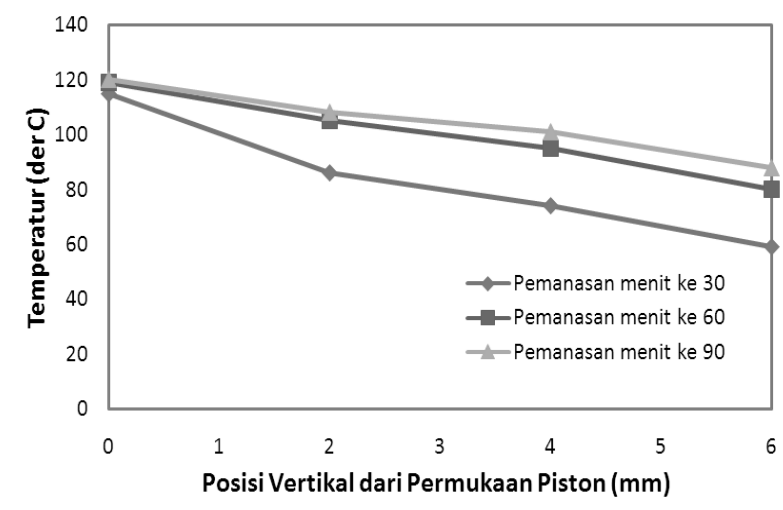

Gambar 5. Distribusi Temperatur ke Aarah Vertikal pada Pemanas Tunggal

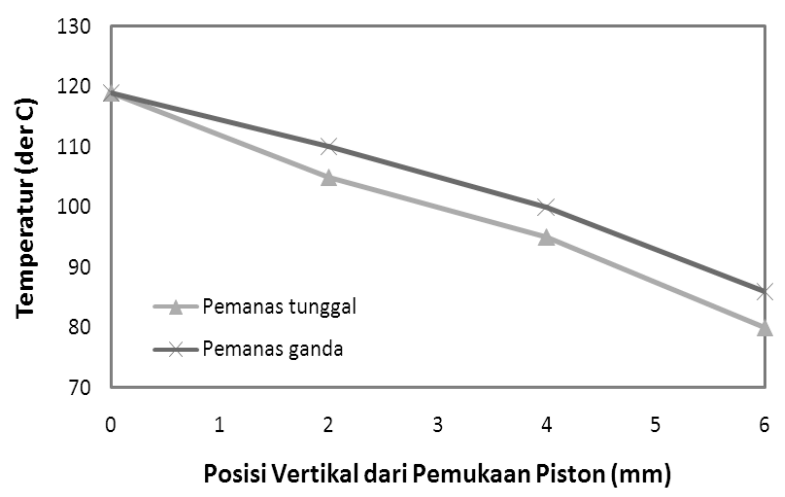

Gambar 6. Distribusi Temperatur Build Part ke Arah Vertikal dengan Pemanas Tunggal dan Ganda

\section{Variasi Ukuran Partikel Serbuk}

Laju pemanasan supporting powder dipengaruhi oleh ukuran partikelnya dimana penurunan laju pemanasan sebanding dengan penurunan ukuran partikelnya seperti ditunjukkan dalam 
Gambar 7. Untuk bahan silika dengan konduktivitas termal 1,7 W/mK, pengecilan ukuran partikel meningkatkan luas permukaan total partikel yang berarti pula meningkatkan energi pemanasannya. Namun apakah kondisi ini berlaku untuk bahanbahan yang memiliki harga konduktivitas termal lebih tinggi? Hal tersebut harus dibuktikan dengan pengujian lainnya. Hingga menit ke 90 ketiga ukuran partikel tidak menghasilkan temperatur yang sama di lokasi $2.3 \mathrm{~cm}$ dari sumber panas (dinding build part).

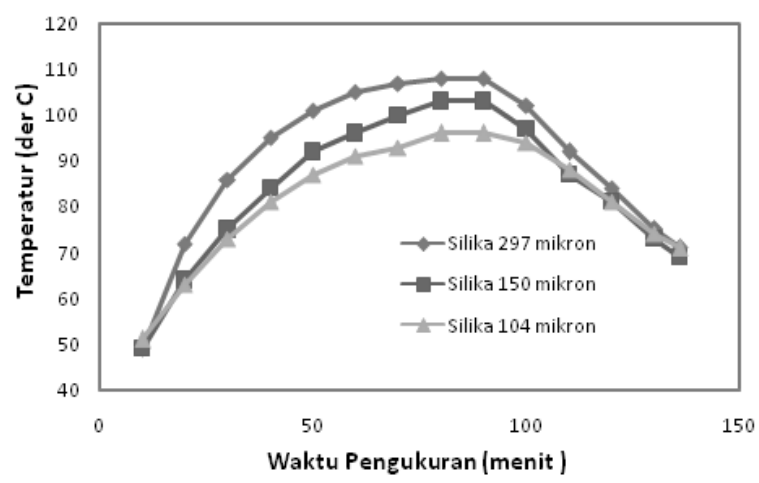

Gambar 7. Temperatur pada Berbagai Ukuran Partikel Supporting Powder (serbuk silika, pemanas tunggal).

\section{Variasi Jenis Bahan Supporting Powder}

Pada benda padat, kemampuan perambatan panas bahan dinyatakan dalam konduktivitas jenis bahan seperti ditunjukkan dalam Tabel 1. Namun bila bahan berupa serbuk selain konduktivitas jenis, kemampuan merambatkan panas dipengaruhi oleh ukuran partikel dan bentuk partikel yang dikonversikan menjadi tingkat kepadatan serbuk tersebut. Ukuran partikel yang semakin besar dan bentuk partikel yang semakin acak menurunkan densitas serbuk yang berarti prosentase rongga semakin besar, dimana rongga tersebut terisi oleh udara dengan karakteristik termal yang berbeda. Kondisi lain terjadi bila ukuran partikel serbuk diperkecil yang berarti luasan total permukaan partikel diperbesar. Pengecilan ukuran partikel menyebabkan peningkatan energi yang dibutuhkan untuk proses pemanasannya seperti dibuktikan dalam Gambar 7 di atas.

Dari hasil pengujian perambatan panas dengan menggunakan jenis supporting powder yang berbeda (silika, besi cor, aluminium dan kuningan) diperoleh bahwa kurva temperatur aktual sebagai fungsi waktu memiliki kecenderungan yang relatif sama seperti ditunjukkan dalam Gambar 8, padahal konduktivitas jenis bahan berbeda (Tabel 1). Dihubungkan dengan tingkat kepadatan serbuk yang disebabkan oleh faktor bentuk partikel (bentuk partikel masing-masing serbuk ditunjukkan dalam

Gambar 9), dari hasil pengukuran masing-masing jenis serbuk memiliki densitas aktual yang berbeda seperti dinyatakan dalam Tabel 2. Aluminium misalnya memiliki konduktivitas jenis tertinggi di antara material kuningan, besi cor dan silika, tetapi pada pengujian ini prosentase rongga sekitar 65,2\%. Sebaliknya untuk bahan silika yang memiliki konduktivitas termal paling rendah yaitu $2,7 \mathrm{~W} / \mathrm{mK}$ memiliki kemampuan hantaran panas yang relatif sama dengan bahan aluminium (Gambar 8). Dari hasil perhitungan densitas aktualnya ternyata serbuk silika memiliki prosentase rongga terendah (densitas tertinggi) dibandingkan serbuk lainnya yaitu $34,5 \%$.

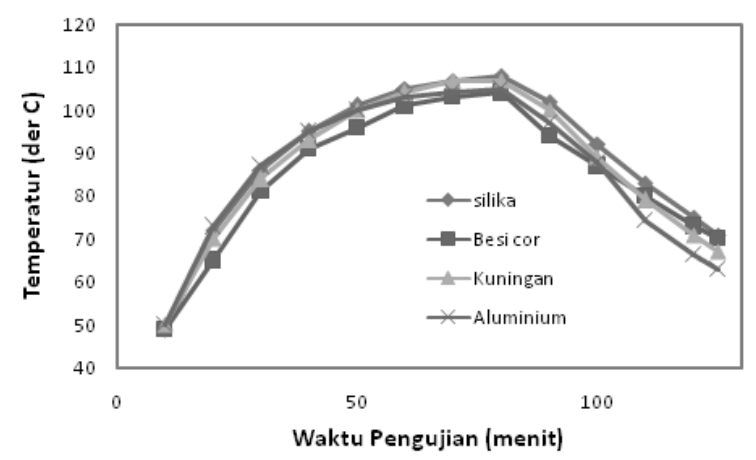

Gambar 8. Temperatur Build Part untuk Berbagai Jenis Bahan Supporting Powder (temperatur pemanasan hingga $123^{\circ} \mathrm{C}$, ukuran partikel 149$297 \mu \mathrm{m}$, posisi pengukuran $2 \mathrm{~cm}$ dari permukaan piston, $6 \mathrm{~cm}$ dari dinding build part).

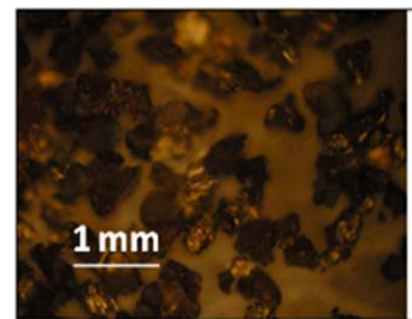

Partikel besi cor Densitas Padat 7,9 kg/l Densitas serbuk $1,81 \mathrm{~kg} / \mathrm{l}$ rongga $75,8 \%$

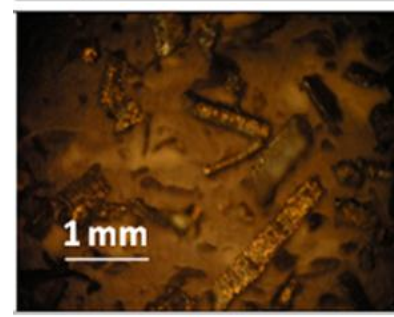

Partikel kuningan

Densitas Padat $8,4 \mathrm{~kg} / \mathrm{l}$

Densitas serbuk $2,55 \mathrm{~kg} / \mathrm{l}$ rongga $69,6 \%$

Gambar 9. Pengaruh Bentuk Partikel Serbuk pada Densitas Aktual Serbuk Tanpa Proses Pemadatan 
Pengaruh densitas bahan pada kemampuan penghantaran panas dengan jelas ditunjukkan pada perbandingan kurva perambatan panas antara piston dengan serbuk aluminium (titik uji terletak di tengah piston). Hasil pengujian (ditunjukkan dalam Gambar 10) memperlihatkan bahwa laju perambatan panas bahan padat lebih tinggi dibandingkan bahan serbuk. Pada pengujian ini densitas aktual serbuk aluminium sekitar $34,8 \%$.

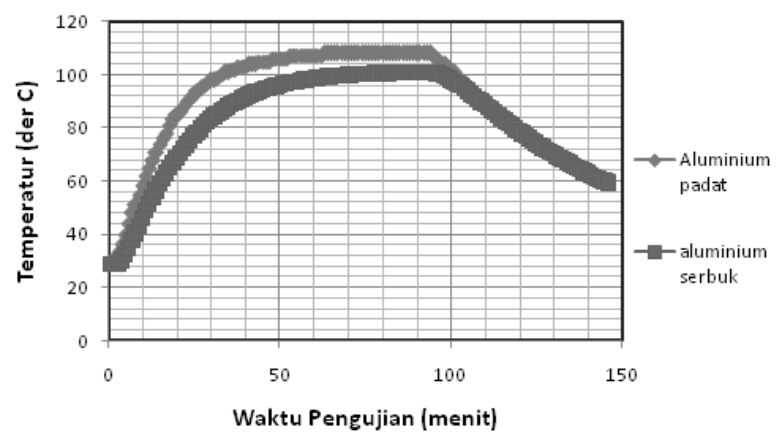

Gambar 10. Karakteristik Termal Bahan Aluminium Padat dan Serbuk (partikel serbuk aluminium 297 mikron).

\section{Perhitungan Nilai Konduktivitas Termal Efektif Serbuk}

Dengan Persamaan 6 dan 7 pengaruh densitas serbuk pada konduktivtas termal dapat dibuktikan untuk mengklarifikasi hasil pengujian. Perhitungan konduktivitas efektif serbuk dinyatakan sebagai berikut:

Untuk serbuk silika

- Fraksi padat

$$
\mu=\frac{1.437 \mathrm{~g} / \mathrm{cm}^{3}}{2.20 \mathrm{~g} / \mathrm{cm}^{3}}=0.653
$$

- Konduktivitas efektif

$$
\begin{aligned}
\mathrm{ke} & =\frac{0.653 \times 1.40 \mathrm{~W} / \mathrm{mK}}{1+0.02 \times 10^{2(0.7-0.653)} \times \frac{1.40 \mathrm{~W} / \mathrm{mK}}{0.0334 \mathrm{~W} / \mathrm{mK}}} \\
& =\frac{0.9142}{1.0409} \mathrm{~W} / \mathrm{mK}
\end{aligned}
$$

Dengan metode perhitungan yang sama diperoleh harga konduktivitas efektif untuk masing-masing jenis serbuk seperti ditunjukkan dalam Tabel 2.

Tabel 2. Nilai Perbandingan Densitas dan Konduktivitas Termal

\begin{tabular}{lccccc}
\hline \multirow{2}{*}{$\begin{array}{l}\text { Jenis } \\
\text { material }\end{array}$} & \multicolumn{2}{c}{ Densitas $\boldsymbol{\rho}\left(\mathbf{g} / \mathbf{c m}^{3}\right)$} & \multicolumn{3}{c}{$\begin{array}{c}\text { Konduktivitas } \\
\text { Termal k (W/mK) }\end{array}$} \\
\cline { 2 - 6 } & $\begin{array}{c}\text { Padat Serbuk } \\
\boldsymbol{\rho}_{\mathbf{s}}\end{array}$ & $\boldsymbol{\rho}_{\mathbf{p}}$ & $\boldsymbol{\rho}_{\mathbf{p}} / \boldsymbol{\rho}_{\mathbf{s}}$ & $\begin{array}{c}\text { Padat } \\
\boldsymbol{k}_{\boldsymbol{s}}\end{array}$ & Serbuk $\boldsymbol{k}_{\boldsymbol{e}}$ \\
\hline Silika & 2,2 & 1,437 & 0,653 & 1,4 & 0,878 \\
Besi cor & 7,15 & 1,805 & 0,252 & 46 & 0,053 \\
Aluminium & 2,71 & 0,936 & 0,345 & 208,07 & 0,112 \\
kuningan & 8,53 & 2,546 & 0,298 & 131,68 & 0,079 \\
\hline
\end{tabular}

Dari Tabel 2 tersebut ditunjukkan bahwa serbuk silika memiliki konduktivitas efektif tertinggi dibandingkan serbuk lainnya seperti ditunjukkan dalam Gambar 8.

\section{KESIMPULAN}

Distribusi temperatur build part dalam arah vertikal tidak merata baik untuk pemanas tunggal maupun pemanas ganda. Peningkatan temperatur terjadi bila posisi semakin mendekati piston. Pada posisi tersebut sumber panas berasal dari sistem pemanas maupun dari permukaan piston yang disebabkan konduktivitas termal bahan padat piston jauh lebih baik dibandingkan konduktivitas termal supporting powder.

Karakteristik termal build part secara dominan dipengaruhi oleh densitas aktual serbuk dan tidak oleh densitas padat bahan supporting powder. Densitas aktual serbuk dipengaruhi oleh bentuk partikel.

\section{DAFTAR PUSTAKA}

1. Widyanto, S.A., Proses Multi Material Deposition Indirect Sinterirng (MMD-Is), Disertasi, Jurusan Teknik Mesin, Universitas Gadjah Mada, 2009.

2. Argento, C. and Bouvard, D., Thermal conductivity of granular media, Powders \& grains, Balkema, Rotterdam, pp.129, 1993.

3. Froment, G.F. and Bischop, K.B., Chemical Reactor Analysis and Design, John Wiley \& Sons, New York, 1990.

4. Borkink J.G. and Westerterp, K.R., Influence of tube particle diameter on heat transport in packed beds, AIChEJ, pp. 38, 703, 1992.

5. Yovanovich, M.M., Thermal contact resistance across elastically deformed spheres, J.Spacecraft Rockets, vol. 4, pp. 119, 1967.

6. Holm, R, Electrical Contacts: Theory and Application, Springer-Verlag, New York, 1967.

7. Yagui, S. and Kunni, D., Studies on effective thermal conductivities in packed beds, J. AIChe, vol. 3, no. 3, pp. 373-381, 1989. 